\title{
COMPARISON OF ENERGY CONSUMPTION IN DIFFERENT WHEAT PRODUCTION TILLAGE SYSTEMS UNDER EGYPTIAN CONDITIONS
}

\author{
G. M. Nasr ${ }^{1}$ - R. M. M. El-Kilani ${ }^{2}$ - Anhar. M.Saeed ${ }^{3}$
}

\section{ABSTRACT}

The present research was conducted in Kafr-Abou-Shehata, Minya el Qamh, Al Sharqia Governorate, Egypt during the season 2011 - 2012 of irrigated wheat production. The aims of this research were to 1) determine the amount of inputs energy for different tillage systems. 2) Selecting the most suitable mechanized system for wheat crop production. Data was collected from three different sources: literature review, questionnaire and field measurements. Statistical analysis system program (SAS) has been used to analyze data with randomized complete block design for the three tillage systems tested in this study with three replications. The tillage systems were: (S1) Chisel plow (1stpass\&2ndpass) +steel leveller wooden ridger + mounted seed drill+ irrigation by sprinkler system +broadcasting fertilizer mechanically + hydraulic sprayer+ self-propelled mower +trailer+ stationary threshing machine, (S2) Mould board plow + disc harrow and $\left(S_{3}\right)$ Disc plow+ disc harrow, the other agricultural operation were performed mechanically using the same equipment as in S1. Wheat yield parameter and energy indices (net energy gain, energy ratio, and energy productivity) were determined. There were significant differences (5\% probability level) among the systems in terms of energy indices (energy ratio and net energy gain), while the value of energy productivity were not significantly differentes. Also there were significant differences (5\% probability level) among the systems in terms of yield, input energy and output energy values but grain and harvest index were not significantly differentes. It was found that Slhad the highest yield and S3 had the lowest.

\footnotetext{
${ }^{1}$ Professor, Agric. Eng. Dept. Faculty of Agriculture - Cairo University.

${ }^{2}$ Associate Professor, Soils and water Dept. Faculty of Agriculture - Cairo University.

${ }^{3}$ Ph. D Student, Agric. Eng. Dept. Faculty of Agriculture - Cairo University.
} 
S1 had the highest net energy gain while S3had the lowest. S3 had the lowest energy ratio and energy productivity and Slhad the highest energy ratio and $S 2$ had the highest energy productivity. The least energy consumed For wheat produced was 5.928 MJ/fed for S2 and the highest was $6.143 \mathrm{MJ} / \mathrm{fed}$ for S3. Energy consumed in MJ/fed for tillage were 286.12, 277.17 and 305.06 for the three systems respectively. Therefore it was concluded that system $S 2$ was the most efficient in this research.

Keywords: Tillage, Energy, wheat, Plow, Net energy gain, Energy productivity

\section{ITRODUCTION}

$\mathrm{E}$

nergy is one of the most important elements in modern agriculture. Without energy, farming is impossible; extremely abundant especially, as modern agriculture depends totally rely on energy use of fossil resources. Energy consumption in agriculture has been increasing in response to the limited supply of arable land, increasing population, technological changes, and a desire for higher standards of living (Hatirli et al., 2006; Kizilaslan, 2008; Manaloor and Sen, 2009).

Agriculture is both a consumer and a producer of energy. Agriculture is an energy conversion process. It converts two naturally abundant materials, water and carbon dioxide, to carbohydrate and other complex organic materials through the photosynthetic process and conserves and recycles mineral resources (Pimentel \& Pimentel, 2008 and Tester, 2005).

Most energy demand from arable and horticultural farming is for fuel. Fuel is consumed for agricultural operations, such as tillage, planting, fertilizer distribution, spraying, and harvesting. New farming operational methods, such as strip tills, minimum tillage, and conservation tillage, have been introduced to replace conventional tillage to save time, costs and fuel and to reduce environmental impacts due to soil erosion and $\mathrm{CO}_{2}$ emission by reducing the number of passes made by tractors on farms (McLaughlin et al.,2008; Smil, 2008).

Tillage can be defined as mechanical or soil-stirring actions exerted on soil to modify soil conditions for the purpose of nurturing crops. The aim of these actions is to provide a suitable environment for seed germination 
and crop root development while suppressing weeds, controlling soil erosion, and maintaining adequate soil moisture (El Titi, 2002). Also Tillage, the mechanical manipulation of soil, is a common practice in recent farming. Tillage improves decomposition of crop residues through physical breakdown and incorporation into soil. Tillage is also used to level soil, seedbed preparation for planting, and incorporation of fertilizers, manures and pesticides. Furthermore, it can serve as a method of post-emergence weed control and as a management instrument to disrupt or reduce the incidence of diseases and pests. (Hossein et al., 2012).

In the cultivation of arable crops, soil tillage is one of the greatest energy and labor consumers. Primary tillage practices require $75 \%$ of the total energy consumed before seed-time (Pelizzi et al., 1988).Therefore; the selection of an appropriate tillage method includes assessments of the system's energy conservation and environmental pollution control. Borin et al.(1997) reported that $30 \%$ of energy in the field is consumed by tillage. Reducing tillage intensity decreases fuel consumption, increases the energy ratio, controls soil erosion, and reduces time and energy required for seedbed preparation ( Kepner et al., 1978). Bonari et al. (1995) reported that reduced tillage results in 55\% less fuel consumption than conventional tillage without a significant difference in crop yield. Chaplin et al.(1988)studied drawbar energy use for different tillage systems, including the moldboard plow and drill, chisel plow and drill, and no-till and drill. They reported that no-till and reduced tillage systems decreased drawbar energy use by $84 \%$ and $54 \%$, respectively. Kosutic et al. (2005) investigated the effect of different tillage systems on energy consumption in crop production in Slovenia. Tillage systems and implements were: conventional system- ploughing, disc-harrow and combined implement (CT) conservation system-chisel plough and multitillage (RT) and no-till system (NT). The energy requirements of the different tillage systems and their influences on yield were compared. Results indicated that the CT system was the greatest energy consumer with $1.8 \mathrm{GJha}^{-1}$. The RT system with chisel plough and multi-tiller consumed $1.1 \mathrm{GJ} \mathrm{ha}^{-1}$, or $37.5 \%$ less than the CT system, while the NT system required $85.1 \%$ less energy than the CT system, or $0.27 \mathrm{GJha}^{-1}$. To 
adequately evaluate crop production tillage energy requirements and choose alternative crop production systems, energy data must be collected for implements used and the soils of major crop production systems. Tillage energy requirements for conventional, minimum, and no-till production systems can then be thoroughly evaluated.

Yousif (2011) mentioned that the crop yield is an important indicator in the evaluation of the different systems of seedbed preparation and planting. He also, compared four systems S1 (chisel plow $1^{\text {st }}$ pass followed by disc harrow, land leveler and ridger), S2 (chiselplow $1^{\text {st }}$, $2^{\text {nd }}$ pass following by disc harrow, land leveler and ridger), S3 (disc plow followed by disc harrow, land leveler and ridger) and S4 (rotary plow followed by ridger) in Sesame production. The Seedbed preparation system can be arranged according to the resulted yields at the optimum method, in the following descending order: $\mathrm{S} 4<\mathrm{S} 3<\mathrm{S} 2<\mathrm{S} 1$.

The highest yield in optimum planting was obtained by using the S4(rotary plow followed by ridger). This trend may be due to the fact that, excessive tillage can cause very fine particles with less volume which produced a high bulk density porosity and void ratio.

Wheat is the most widely grown cereal crop in the world. Moreover; it has been considered the first strategic food crop. It is the main diet for the Egyptian population. According to FAO (2012) wheat is cultivated on 1, 350,000 hectare with a production of $8,796,000$ tons with an average yield of 6.51 tons per hectare. This makes the assessment of the energy indices for wheat cultivation essential and justifiable. The aims of this research were to 1) determine the amount of inputs energy for different tillage systems. 2) Selecting the most suitable mechanized system for wheat crop production.

\section{MATERIALS AND METHODS}

\section{First step: - Collecting data.}

Data was collected from three different sources:

A. Literature review: - Some of the data used in this research were obtained from literature cited.

B. Questionnaire: - Data collection was an important part of this research. Farmer's responses were obtained mainly through face to face 
interviews conducted in Kafr-Abou- Shehata, Minya el Qamh, Al Sharqia Governorate in Egypt during the season $2011-2012$.

Data collected from questionnaire included:

1) Simple personal information such as age, education and relevant experiences (by year).

2) Number of farm animals.

3) Simple information about farm and production

4) Type and amounts of seed, fertilizers, and chemicals.

5) Involved Irrigation system, irrigation frequency, irrigation duration (h) and Fuel consumption ( $1 / \mathrm{h})$.

6) Type and number of field operations, number of labors, power and age of tractors, self- propelled mower and combines, and size and age of equipment.

C. Field measurements: The energy inputs estimated in this research are those that go into on-farm production systems before the post-harvest processes. The field measurements data were obtained from Kafr-Abou- Shehata, Minya el Qamh, Al Sharqia Governorate in Egypt during the season of 2011 - 2012, some of these measurements were fuel consumption, as well as the ground speed and width of equipment.

\section{- Energy Sources}

The inputs in energy analysis in wheat production included direct operational energy consumption such as, human, animal power, fuel consumption and indirect energy sources (fertilizer, pesticides and seed).

\section{a) Human (Labour)}

In this research, the number of worker input was obtained by the questionnaire and then the work done for each operation was estimated. However, it was difficult to estimate human energy use in operations such as tractor servicing which also contributed to other farm products. It was clear that farmers expended different amounts of energy per hour for each operation and several factors, such as gender, weight, and age can influence their energy use (Mani et al., 2007). Human energy was calculated from the following equations:

$$
E_{h}=\frac{0.1 \times n}{1.36 \times \text { A.F.C }} \times 3.6
$$




$$
E_{h}=\frac{0.264 \times n}{\text { A.F.C }}
$$

\section{Where}

Eh: Human energy (MJ/fed).

$\mathrm{n}$ : Number of workers required for operation.

A. F. C: Actual field capacity of the gang of workers (fed/h).

1.36: Coefficient for transformation from $\mathrm{HP}$ to $\mathrm{kW}$.

0.1: Human power (HP)

3.6: Coefficient for transformation from kW.h to MJ

\section{b) Animal power}

Like tractors, draft animals can provide the motive power for leveling by using wooden leveler, dividing by using wooden ridger and transporting inputs and outputs inside and outside farm. They may also be used for plowing, planting, cultivating and harvesting agronomic or field crops. Animal energy was calculated from the following equation

$$
\begin{gathered}
\mathbf{E a}=\frac{0.5 \times n}{1.36 \times \text { A.F.C }} \times 3.6 \\
\mathbf{E a}=\frac{1.323 \times n}{\text { A.F.C }}
\end{gathered}
$$

\section{Where}

Ea : Animal energy (MJ/ fed).

$\mathrm{n}$ : Number of farm animals used

A. F. C : Actual field capacity of the team of animals (fed/h).

1.36: Coefficient for transformation from $\mathrm{HP}$ to $\mathrm{kW}$.

0.5: Animal (Oxen) power (HP).

3.6: Coefficient for transformation from $\mathrm{kW}$. h to MJ

c) Energy consumed in operating the machinery

The main input into mechanical energy source was fuel. Fuel consumption field measurements; was performed by filling the tractor tank twice, before and after each operation. Fuel energy was calculated from the following equations:

$$
E_{m}=\text { F.C } \times \frac{1}{60 \times 60} \times \rho_{f} \times C . V . \times 427 \times \frac{1}{75} \times \frac{1}{1.36} \times \frac{1}{A . F . C}
$$




$$
\begin{gathered}
E_{m}=\frac{F . C \times 9.884}{A . F . C} \times 3.6-----(6) \\
E_{m}=\frac{35.58 \times F . C}{A . F . C}-\cdots----(7)
\end{gathered}
$$

\section{Where}

$\mathbf{E}_{\mathbf{m}}$ : Mechanical energy consumed in operating the machinery (MJ/fed).

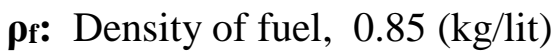

C.V. : Calorific value of fuel, 10000 (kCal./kg)

427: Constant (thermo -mechanical equivalent) (kg.m / kcal)

1.36: Coefficient for transformation from $\mathrm{HP}$ to $\mathrm{kW}$.

F.C: Fuel consumption $(1 / \mathrm{h})$.

A.F.C: Actual field capacity (fed/h).

3.6: Coefficient for transformation from $\mathrm{kW} . \mathrm{h}$ to $\mathrm{MJ}$

\section{d) Fertilizers}

Fertilizers were one of the most significant energy inputs on arable farms. In this study, the energy consumption for fertilizer production was determined through multiplying the basic energy used for the manufacture for $\mathrm{N}$ and $\mathrm{P}$ fertilizers by the percentage of these elements in the final fertilizer. Farmers in Kafr-Abou-Shehata predominantly added organic fertilizer (manure) at a rate of $20 \mathrm{~m}^{3} / \mathrm{fed}$, because organic fertilizer works to improve the properties of the soil. And also, farmers used chemical fertilizer such as Superphosphate has been added with rate of $15 \mathrm{~kg} / \mathrm{fed}$ and Nitrogen fertilizer has been added with rate of 75 $\mathrm{kg} / \mathrm{fed}$. In this study, the energy equivalents for manure, $\mathrm{N}$ and $\mathrm{P}$ were obtained from table 1 .

Table 1. Energy equivalents of inputs in wheat production

\begin{tabular}{lcl}
\hline Input & Energy equivalent(MJ/kg) & Reference \\
\hline Manure & 0.3 & Verma(1987) \\
Chemical fertilizer & & \\
$\mathrm{P}_{2} \mathrm{O}_{5}$ & 12.44 & Shrestha (1998) \\
Nitrogen & 66.14 & Shrestha (1998) \\
\hline
\end{tabular}




\section{e) Chemicals}

The most common agrochemicals used in Kafr-Abou- Shehata to fight against weeds and insects on wheat farms were Granular using $8 \mathrm{~g} / \mathrm{fed}$, Topic using $140 \mathrm{~g} / \mathrm{fed}$ and Afox using $21.2 \mathrm{~g} / \mathrm{fed}$.

Hydraulic sprayer was used to apply agrichemicals to fight wheat farm weeds and pests.

Energy consumption was determined by multiplying the energy equivalent of the agrochemical compound by the total applied amount of used herbicides and insecticides. In this study, the energy coefficients for herbicides and insecticides were taken as shown in table 2

Table 2. Energy equivalents of inputs in wheat production

\begin{tabular}{lcl}
\hline Input & Energy equivalent $(\mathbf{M J} / \mathbf{~ k g})$ & \multicolumn{1}{c}{ Reference } \\
\hline Granular & 120.00 & Chaudhary et al. (2006) \\
Topic & 271.38 & Mohammadi et al. $(2008)$ \\
Pesticide & 280.44 & Mohammadi et al. $(2008)$ \\
\hline
\end{tabular}

\section{f) Seeds}

In Kafr-Abou- Shehata, clean and certified seeds are provided in packages from the seed producer companies; however, some farmers still use their own seeds. In this study, the mounted seed drill was used for planting at a seeding rate of $50 \mathrm{Kg} /$ fed. The energy equivalent for wheat seed 14.70 MJ/kg (Richard, 1992).

\section{Second step: -Energy analysis}

In this research, energy consumption in wheat production was analyzed based on direct energy sources and indirect energy sources. Direct energy includes human energy, animal energy, and fuel energy. While indirect energy included fertilizers, chemical and seed. The total energy input was calculated from the following equation:-

$$
E=\Sigma\left(A_{i} C_{i}\right)
$$

\section{Where}

E:-The total energy input (MJ/fed)

$\mathbf{A}_{\mathbf{i}}$ :- The amount of input factor

$\mathrm{C}_{\mathrm{i}:-}$ - Appropriate energy conversion coefficient for that factor.

The operations for which energy inputs are estimated for on - farm production systems include, seedbed preparation, leveling, dividing, 
seeding, irrigation, fertilizing, and weed control, harvesting, transporting and threshing as shown in Table 3.

Table 3. The three different systems of wheat production

\begin{tabular}{lc}
\hline System & components \\
\hline S1 & Chisel plow $\left(1^{\text {st }}\right.$ pass\& $2^{\text {nd }}$ pass $)$. \\
S2 & Mouldboard plow + disc harrow. \\
S3 & Disc plow + disc harrow. \\
\hline
\end{tabular}

\section{Evaluation parameters}

Four estimated quantities were used to evaluate the performance and set up the most visible wheat production system. These quantities are net energy gain, energy ratio, energy productivity, specific energy. The evaluation parameters were calculated as indicate with following relations:-

$$
\begin{gathered}
\text { Net energy gain }(\mathrm{MJ} / \mathrm{fed})=\text { Energy Output }- \text { Energy Input ...(9) } \\
\text { Energy ratio }=\frac{\text { Energy Output }}{\text { Energy Input } \ldots \ldots . . .(10)} \\
\text { Energy Productivity }(\mathrm{Kg} / \mathrm{MJ})=\frac{\text { Grain output }}{\text { Energy Input }} \ldots \ldots . . .(11) \\
\text { Specific energy }(\mathrm{MJ} / \mathrm{Kg})=\frac{\text { Energy Input }}{\text { Grain Output }}(12)
\end{gathered}
$$

Table 4. Energy equivalent of inputs and outputs in wheat production.

\begin{tabular}{lcl}
\hline Particulars & Energy equivalent(MJ/kg) & \multicolumn{1}{c}{ Reference } \\
\hline $\begin{array}{l}\text { Input(kg) } \\
\text { Chemicals }\end{array}$ & & \\
$\quad \begin{array}{l}\text { Granular } \\
\text { Topic }\end{array}$ & 120.0 & $\begin{array}{l}\text { Chaudhary et al (2006) } \\
\text { Pesticide }\end{array}$ \\
$\begin{array}{l}\text { Organic fertilizer } \\
\quad \text { Manure }\end{array}$ & 271.38 & Mohammadi et al(2008) \\
Chemical fertilizers & 280.44 & \\
$\quad\left(\mathrm{~N}_{2}\right)$ & 0.3 & Verma(1987) \\
$\quad\left(\mathrm{P}_{2} \mathrm{O}_{5}\right)$ & 66.14 & \\
Output $(\mathbf{k g})$ & 12.44 & Shrestha (1998) \\
Grain wheat & & Shrestha (1998) \\
Straw & 14.70 & Richard (1992) \\
\hline
\end{tabular}




\section{RESULTS AND DISCUSSION}

Statistical analysis system (SAS) had been used to analyze the obtained data of the tested tillage systems. The experiment was statistically designed in randomized complete block with three replications.

\section{Wheat yield parameter}

Based on the analysis of variance, wheat yield values were found to be different in different tillage systems at the 5\% level of significantly. Table 5 and Fig.1 indicate that (S1) had the highest yield (grain + straw) of $6541 \mathrm{~kg}$ / fed while lowest yield was recorded for S3 (6431 kg / fed).

\section{Table 5.Wheat yield parameters}

\begin{tabular}{|c|c|c|c|c|}
\hline \multicolumn{2}{|c|}{ System } & Grain (kg / Fed) & yield (kg / Fed) & Harvest index \\
\hline \multicolumn{2}{|l|}{ S1 } & 2381 & 6541 & 0.3640 \\
\hline \multicolumn{2}{|l|}{$\mathbf{S 2}$} & 2451 & 6521 & 0.3759 \\
\hline \multicolumn{2}{|l|}{ S3 } & 2370 & 6431 & 0.3685 \\
\hline \multicolumn{2}{|c|}{ L.S.D. 5\% } & 112.37 NS & $6.5441 * *$ & 0.0174 NS \\
\hline \multicolumn{5}{|c|}{ ** significant } \\
\hline \multirow[t]{2}{*}{ 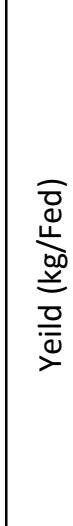 } & $\begin{array}{l}6560 \\
6540 \\
6520 \\
6500 \\
6480 \\
6460 \\
6440 \\
6420 \\
6400 \\
6380 \\
6360\end{array}$ & 6541 & 6521 & 6431 \\
\hline & & S1 & $\begin{array}{r}\text { S2 } \\
\text { Systems }\end{array}$ & S3 \\
\hline
\end{tabular}

Fig.1 Total wheat yield (kg/fed) by the tested systems

The obtained results came similar to what had been found by Moreno et al., (1997) reported higher winter wheat yield under conventional than traditional tillage but differences weren't significant. Lyon et al., (1998) found an $8.0 \%$ greater winter wheat yield with conventional tillage than 
with no-tillage. Lawrence et al., (1994) in a 4- year study showed that no-till had a higher wheat yield than did reduced or conventional tillage. Arshad and Gill (1997), comparing conventional reduced and zero tillage (no-till) systems found during 3 years of testing the greatest average wheat yield for reduced tillage, while conventional tillage had the lowest.

\section{Energy indices}

\section{1) Net energy gain}

Comparisons between the systems on net energy gain parameter showed significant differences at the 5\% level. It is revealed from table 6 and fig.2 that S1had the highest net energy gain $72460.294 \mathrm{MJ}$ and S3 had the lowest 71042.147MJ.

Table 6. Comparison of systems on net energy gain

\begin{tabular}{cccc}
\hline System & $\begin{array}{c}\text { Input energy } \\
(\mathbf{M J} / \mathbf{f e d})\end{array}$ & $\begin{array}{c}\text { Output energy } \\
(\mathbf{M J} / \mathbf{f e d})\end{array}$ & $\begin{array}{c}\text { Net energy } \\
\text { gain(MJ/fed }\end{array}$ \\
\hline S1 & 14540.406 & 87000.70 & 72460.294 \\
S2 & 14531.464 & 86904.70 & 72373.236 \\
S3 & 14559.353 & 85601.50 & 71042.147 \\
L.S.D.5\% & $\mathbf{1 2 . 4 9 3 * *}$ & $\mathbf{8 . 5 5 5 9 * *}$ & $\mathbf{1 8 . 2 7 8 * *}$ \\
\hline
\end{tabular}

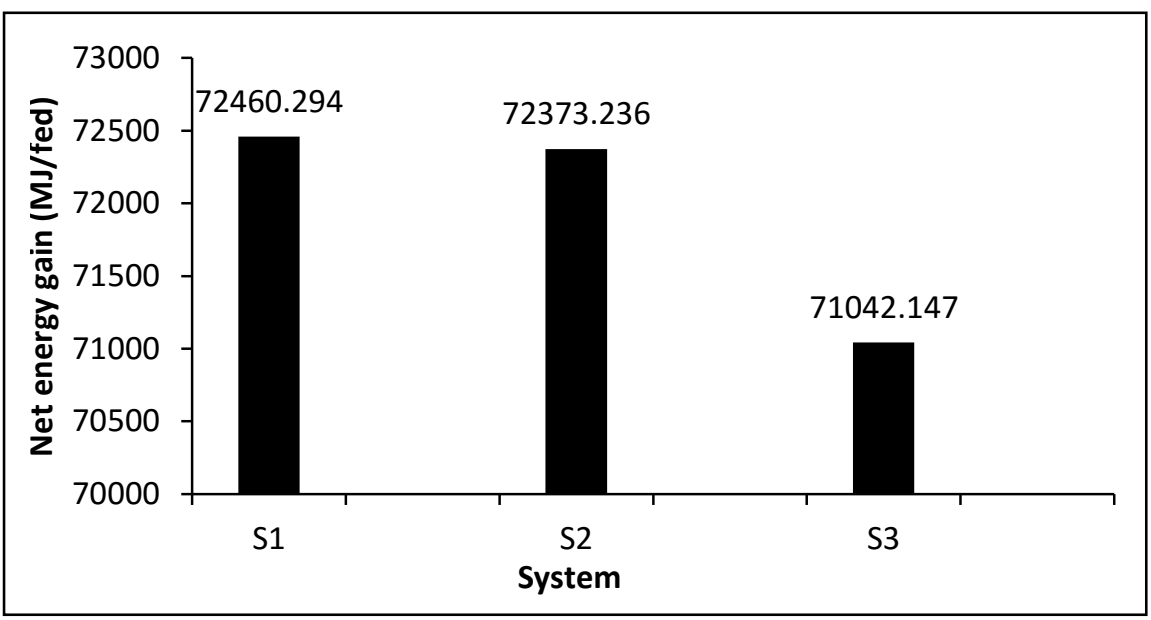

\section{2) Energy ratio}

As it is shown in table 7 there are significant differences at the 5\% level between the systems on energy ratio. It revealed from table 7 and fig. 3 
that S1system had the highest ratio and S3 had the lowest. Input and output energy had an effect on energy ratio, therefore by reducing tillage, input energy decreased but the rate of decrease was low (Borin et al., 1997).

Table 7. Energy indices in different tillage systems for wheat production

\begin{tabular}{lcc}
\hline System & Energy ratio & Energy productivity $(\mathbf{k g} / \mathbf{M J})$ \\
\hline S1 & 5.9833 & 0.1637 \\
S2 & 5.9804 & 0.1686 \\
S3 & 5.8794 & 0.1627 \\
L.S.D.5\% & $\mathbf{0 . 0 0 5 4 * *}$ & $\mathbf{0 . 0 0 7 6 N S}$ \\
\hline
\end{tabular}

If the ratio is higher than one, the system is earning energy, whereas if it is less than one, the system is losing energy. As shown in table 7 the average values of estimated energy ratio for wheat for irrigated farming systems were 5.9833, 5.9804 and 5.8794 respectively indicating that the energy ratio was greater for S1 than S2 and S3. The main difference among the three ratios can be attributed to the output energy of S1 is slightly greater than the output of S2 and S3.

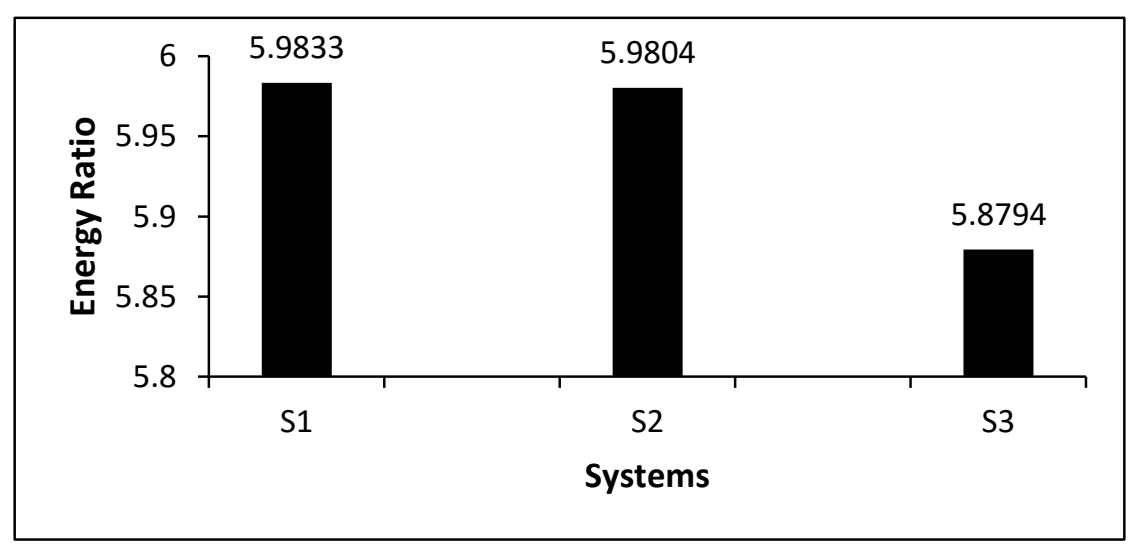

Fig. 3. Energy ratio for the three tested production systems.

\section{3) Energy productivity}

As it is show in table 7 and fig. 4 energy productivity was not 
significantly differentes among systems. S2 had high energy productivity with average 0.1686 and $\mathrm{S} 3$ had a least energy productivity 0.1627 , that means as the value of input energy is lower the energy productivity is higher and vice versa according to equation 7 .

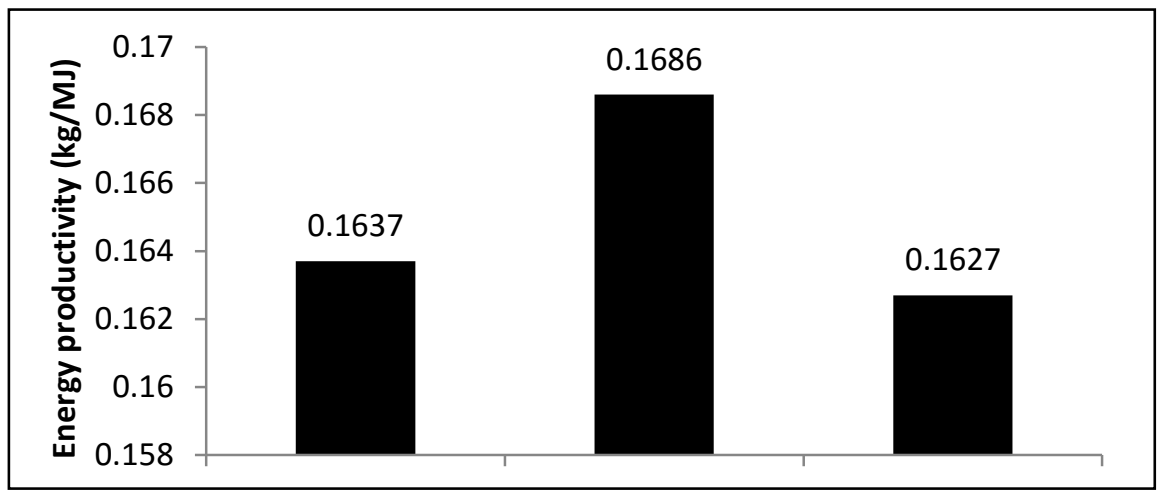

Fig.4 . Energy productivity.

\section{Specific energy consumption}

Specific energy consumption in different tillage systems were compared as shown in table 8 and fig.5. S3 had the highest specific energy consumption $\left(6.143 \mathrm{MJkg}^{-1}\right.$ ) and S2 had the lowest (5.928 $\left.\mathrm{MJkg}^{-1}\right)$. In similar research, a number of field experiments were conducted by (Carman, 1997) on clay soil to determine the effect of different tillage tools on the wheat yield in Middle Anatolia; they reported that tillage systems had a significant effect on wheat yield; the greatest yield was obtained with a stubble cultivator, followed by disc harrowing treatment. System S2 can be recommended in this study because the value of grain in S2 was highest than other systems and also the value of specific energy consumption in system S2 was lowest than other systems.

This conclusion is in close agreement with the findings of (Kosutic et al. 2005) who pointed out that soil tillage systems differ greatly with respect to energy requirement. 


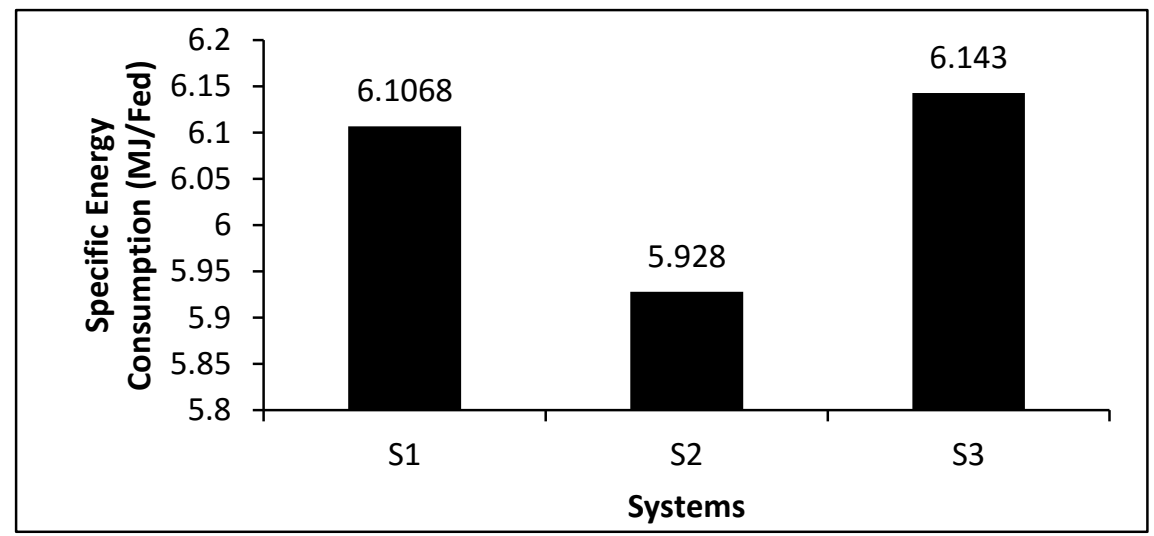

Fig. 5. Specific energy consumption of different tillage.

Table 8. Specific energy consumption for the three tested production systems.

\begin{tabular}{cc}
\hline System & Specific energy consumption $(\mathbf{M J} / \mathbf{k g})$ \\
\hline S1 & 6.1068 \\
S2 & 5.928 \\
S3 & 6.143 \\
\hline
\end{tabular}

The data of table 9 were used for the determination of the consumed energy in performing the required field operations for the different investigated systems. It can be concluded from the data of table 9 that:

- The disc plow consumed energy more than the mouldboard plow, and each consumed energy more than the chisel plow.

-The disc harrow consumed energy about half that consumed by the chisel plow at $2^{\text {nd }}$ pass.

- The chisel plow at $1^{\text {st }}$ pass consumed energy more than that consumed at $2^{\text {nd }}$ pass.

- Energy consumed for tillage in system (S2) when used mouldboard plow and disc harrow was lower while system (S3) when used disc plow and disc harrow was higher. 
Table 9. Number of workers, animals, fuel consumption and consumed energy need for the execution of different operations.

\begin{tabular}{|c|c|c|c|c|c|c|c|c|c|c|}
\hline \multirow{2}{*}{$\begin{array}{c}\text { Equipment } \\
\text { or } \\
\text { method }\end{array}$} & \multirow[b]{2}{*}{ operation } & \multirow{2}{*}{$\begin{array}{l}\text { No. of } \\
\text { worker }\end{array}$} & \multirow{2}{*}{$\begin{array}{c}\text { No. of } \\
\text { animals }\end{array}$} & \multirow{2}{*}{$\begin{array}{c}\text { Fuel } \\
\text { consump } \\
\text { tion. }(1 / h)\end{array}$} & \multirow{2}{*}{$\begin{array}{l}\text { Actual } \\
\text { field } \\
\text { capacity } \\
\text { fed/h }\end{array}$} & \multicolumn{5}{|c|}{$\begin{array}{c}\text { Energy consumption } \\
(\mathrm{MJ} / \mathrm{Fed})\end{array}$} \\
\hline & & & & & & H. & A. & M. & Others & $\begin{array}{l}\text { Total } \\
\text { energy }\end{array}$ \\
\hline Chisel plow & $1^{\text {st }}$ pass & 1 & 0 & 3.79 & 0.87 & 0.30 & 0.00 & 155.01 & 0.00 & 155.31 \\
\hline Chisel plow & $2^{\text {nd }}$ pass & 1 & 0 & 4.00 & 1.09 & 0.24 & 0.00 & 130.57 & 0.00 & 130.81 \\
\hline $\begin{array}{l}\text { Mouldboard } \\
\text { plow }\end{array}$ & $1^{\mathrm{st}}$ pass & 1 & 0 & 4.47 & 0.78 & 0.33 & 0.00 & 203.90 & 0.00 & 204.23 \\
\hline Disc plow & $1^{\text {st }}$ pass & 1 & 0 & 4.69 & 0.72 & 0.36 & 0.00 & 231.76 & 0.00 & 232.12 \\
\hline Disc harrow & $\begin{array}{l}\text { Secondar } \\
\text { y tillage }\end{array}$ & 1 & 0 & 3.60 & 1.76 & 0.15 & 0.00 & 72.790 & 0.00 & 72.94 \\
\hline Steel leveller & levelling & 1 & 0 & 3.78 & 1.18 & 0.22 & 0.00 & 113.97 & 0.00 & 114.19 \\
\hline $\begin{array}{l}\text { Wooden } \\
\text { ridger }\end{array}$ & Dividing & 1 & 2 & 0 & 1 & 0.26 & 2.66 & 0.000 & 0.00 & 2.92 \\
\hline $\begin{array}{l}\text { Mounted } \\
\text { seed- drill }\end{array}$ & Seeding & 1 & 0 & 3.73 & 1.76 & 0.15 & 0.00 & 75.420 & 735.00 & 810.57 \\
\hline $\begin{array}{l}\text { Sprinkler } \\
\text { system }\end{array}$ & Irrigation & 2 & 0 & 0 & 0.05 & 10.58 & 0.00 & 0.00 & 4239.10 & 4249.68 \\
\hline $\begin{array}{l}\text { Mechanical } \\
\text { broadcasting }\end{array}$ & Fertilizing & 1 & 0 & 3.73 & 1.76 & 0.15 & 0.00 & 75.420 & 7997.1 & 8072.67 \\
\hline $\begin{array}{l}\text { Hydraulic } \\
\text { sprayer }\end{array}$ & $\begin{array}{l}\text { Weed } \\
\text { and pest } \\
\text { control }\end{array}$ & 2 & 0 & 6.320 & 0.435 & 1.216 & 0.00 & 516.96 & 45 & 563.17 \\
\hline $\begin{array}{l}\text { Self - } \\
\text { propelled } \\
\text { mower }\end{array}$ & Harvesting & 2 & 0 & 0.62 & 0.60 & 0.882 & 0.00 & 36.75 & 0.00 & 37.63 \\
\hline Trailer & $\begin{array}{c}\text { Transporti- } \\
\text { ng }\end{array}$ & 2 & 0 & 2.85 & 0.82 & 0.64 & 0.00 & 153.64 & 0.00 & 154.28 \\
\hline $\begin{array}{l}\text { Stationary } \\
\text { threshing } \\
\text { machine }\end{array}$ & Threshing & 2 & 0 & 3.70 & 0.66 & 0.792 & 0.00 & 248.4 & 0.00 & 249.19 \\
\hline
\end{tabular}

H: Human energy, A: Animal energy, M: Mechanical energy

\section{CONCLUSION}

This research evaluated the energy indices and wheat yield parameters for different tillage systems in Kafr-Abou- Shehata, Minyael Qamh, Al Sharqia Governorate, Egypt. The methodology used in the calculation of energy use was broken down in to inputs and outputs, with the total input energy being the sum of all components of energy used in the production of the output. The energy ratios were based on the total input and output in the different tillage systems. The inputs and outputs for the production of wheat were multiplied by their energy equivalents. To compare the effects of different tillage systems on the final product, wheat yield parameter was determined. The results showed that the chisel plow system (S1) had the highest yield and disc plow system (S3) had the lowest yield value. It was also revealed that S3 consumed the higher 
energy (6.143 $\mathrm{MJkg}^{-1} \mathrm{MJkg}^{-1}$ ) and $\mathrm{S} 2$ the lower $5.928 \mathrm{MJkg}^{-1} \mathrm{MJkg}^{-1}$ ). Energy productivity for S2 was higher than those for other systems, and energy ratio for $\mathrm{S} 1$ was higher than those for other systems. With regards to the latter results system $\mathrm{S} 2$ is recommended for irrigated land farming of wheat in this research.

\section{REFERENCE}

Abd EI-Ghany, H.M.; Abd EI-Salam, M.S.;Hozyen,M. and Afifi, M.H.M.(2012). Effect of deficit irrigation on some growth stages of wheat. Journal of applied sciences research, 8(5):27762784.ISSN 1819-544X.

Arshad, M.A.and Gill, K.S. (1997). Barley, canola and wheat production under different tillage-fallow-green manure combinations on a clay soil in a cold semiarid climate. Soil Tillage Res, 43:63-275.

Bonari, E.; Mazzoneini, M. and Peruzzi, A.( 1995). Effects of conventional and minimum tillage on winter oil seed rape. Soil Tillage Res, 33(2):91-108.

Borin, M.; Menini, C.and Sartori, L. (1997). Effects of tillage systems on energy and carbon balance in north-eastern Italy. Soil and Tillage Research, Vol. 40: 209-226.

Carman, K. (1997).Effect of different tillage systems on soil properties and wheat yield in Middle Anatolia. Soil Tillage Res, 40(3):201-7.

Chaplin, J.; Jenane, C.and Lueders, M.( 1988). Drawbar energy use for tillage operations on loamy sand. Trans ASAE, 31(6):1692-4.

Chaudhary, V.P; Gangwar, B. and Pandey, D.K. (2006). Auditing of energy use and output of different cropping systems in India.Agricultural Engineering international the CIGR journal. 5:113.

EI -Titi , A. (2002). Soil Tillage in Agro ecosystems. CRC Press. Rar \ Soil_t Tillage _in _ groecosystems_Advances_in_Agroecology_RAR archive, unpacked size 26,818,018 bytes, page : 1-25. 
Embaby, A. T. (1985). A comparison of the different mechanization systems for cereal crop production. M.Sc. thesis, Agric. Eng. Dept. Faculty of agriculture. Cairo University.

FAO(2013).http://www.fao.org/giews/countrybrief/country.jsp?code=EG

Hatirli, S. A.; Ozkan, B., and Fert, C. (2006). Energy inputs and crop yield relationship in greenhouse tomato production. Renewable Energy, 31(4), 427-438.

Hossein,M.R.; Amin,w. and Hoshang, R.(2012). Energy Efficiency of Different Tillage Systems in Forage Corn Production. International Journal of Agriculture and Crop Sciences, Vol., 4 (22), 1644-1652.

Kepner, R.A.; Bainer, R.and Barger, B.L.( 1978). Principles of farm machinery. USA: AVI, Inc.

Kizilaslan, H. (2008). Input-output energy analysis of cherries production in Tokat Province of Turkey. Applied Energy, In Press, Corrected Proof.

Kosutic, S.; Filipovic, D.; Gospodaric, Z.; Husnjak, S.; Kovacev, I.and Copec, K.( 2005). Effects of different soil tillage systems on yields of maize, winter wheat and soybean on albic luvisol in northwest Slavonia. J Central Eur Agric , 6:241-8.

Lawrence, P.A.; Radford, B.J.; Thomas, G.A.; Sinclair, D.P. and Key, A.J. (1994).Effect of tillage practices on wheat performance in a semi-arid environment. Soil Tillage Res, 28:347-64.

Lyon, J.D.; Stroup; W.W. and Brow, R.E. (1998). Crop production and soil water storage in long-term winter wheat-fallow tillage experiments. Soil Tillage Res, 49:19-27.

Manaloor, V., and Sen, C. (2009). Energy Input Use and $\mathrm{CO} 2$ Emissions in the Major Wheat Growing Regions of India. Paper presented at the International Association of Agricultural Economists Conference, Beijing, China. 
Mani, I., Kumar, P., Panwara , S. G., \& Kanta, K. (2007). Variation in energy consumption in production of wheat-maize with varying altitudes in hilly regions of Himachal Pradesh, India energy, 32(12), 2336-2339.

McLaughlin, N. B.; Drury, C. F.; Reynolds, W. D.; Yang, X. M.; Li, Y. X.; Welacky, T. W., and Stewart, G. (2008). Energy Inputs for Conservation and Conventional Primary Tillage Implements in a Clay Loam Soil. ASABE.

Mohammadi, A.; Tabatabaeefar, A.; Shahin Sh, Rafiee Sh and Keyhani, A. (2008). Energy use and economic analysis of potato production in Iran a case study: Ardabil province. Energy Conversion Manage., 49:3566-3570.

Moreno, F.; Pelegrin, F.; Fernandez, J.E.and Murillo, J.M.( 1997). Soil physical properties, water depletion and crop development under traditional and conservation tillage in southern Spain. Soil Tillage Res 1997, 41(1):5-42.

Ozkan, B.; Akcaoz, H., and Fert, C. (2004). Energy input-output analysis in Turkish agriculture. Renewable Energy, 29(1), 39-51.

Pelizzi, G.; Cavalchini, A. and Lazzari, M.( 1988). Energy in agricultural machinery and mechanization. London, New York: Elsevier Applied Sciences.

Pimentel, D. and Pimentel, M. (2008). Food, energy, and society (3rd ed.). Boca Raton, FL: CRC Press.

Richard, C.F. (1992). Energy in farm production. (Elsevier publishing: Netherlands).

Shahram, K. and Houshyar, E. (2012). Energy consumption of rainfed wheat production in conventional and conservation tillage system. International journal of agriculture and crop sciences. IJACS/ 2012/ 4-5/ 213-219. Available online at www.ijagcs.com. 
Shrestha, D.S. (1998). Energy use efficiency indicator for agriculture. http://www.usaskca/agriculture/caedac/PDF/mcrae.PDF; Accessed, March 2012.

Smil, V. (2008). Energy in nature and society: general energetics of complex systems. Cambridge, Mass.: The MIT Press.

Tester, J. W. (2005). Sustainable energy: choosing among options. Cambridge, Mass.: MIT Press.

Verma, S. (1987). Energy in production agriculture and food processing. Prpceeding of the National Conference held at the Punjab Agricultural University, Ludhana. October 30-31.

Yousif, H.S.(2011). Mechanization of seedbed preparation for sesame crop production. M.Sc. thesis, Agric. Eng. Dept. Faculty of agriculture. Cairo University.

الملخص العربى

مقارنة بين الطاقة المستهلكة في نظم الحراثة المختلفة لإنتاج القمح تحت الظروف المصرية

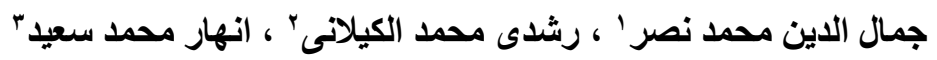

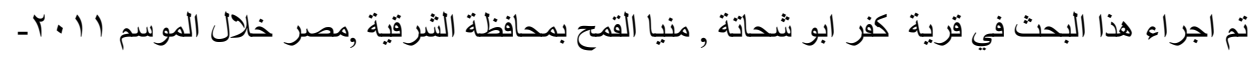

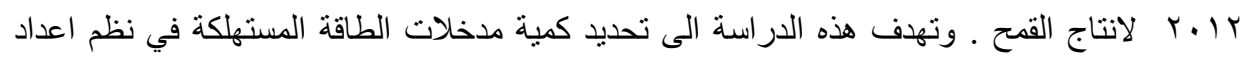
الارض المختلفة وكذلك اختيار النظام الميكانيكي الأكثر ملائمة لإنتاج محصول القمح من بين النظم

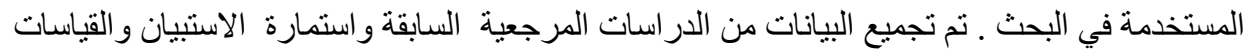
الحقلية العملية .وكانت نظم الاتناج الثلاثة المستخدمة في الدراسة هي : النظام الاول) الذي ينكون من التان

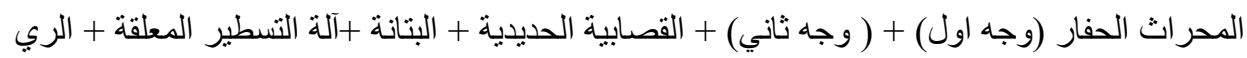

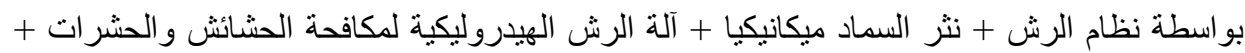
المششة الذاتية الحركة + الدقطورة + آلة الدراس الثابتة.

' استاذ الهندسة الزراعية ـ كلية الزراعة - جامعة القاهرة.

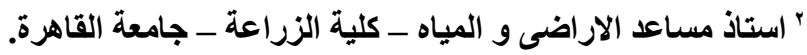

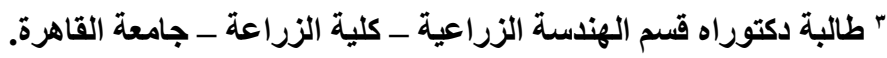


(النظام الثاني) الذي يتكون من المحر اث المطرحي +المشط القرصي، ( النظام الثالث) الذي يتكون من المحر اث القرصي + المشط القرصي أجريت العملية الزر اعية الأخرى ميكانيكيا باستخدام نفس المعدات كما هو الحال في النظام الاول. وتم حساب معايير انتاج القمح ومؤشرات الطاقة (صافي ربح الطاقة, نسبة الطاقة , انتاجية الطاقة). سجل النظام الاول اعلى غلة للقمح والنظام الثالث اقل غلة للقمح. سجل النظام الاول اعلى صافي ربح الطاقة بينما النظام الثالث سجل اقل صافي ربح الطاقة. سجل النظام الثالث اقل نسبة الطاقة و انتاجية الطاقة و النظام الاول كان اعلى في نسبة الطاقة و النظام الثاني كان الاعلى في

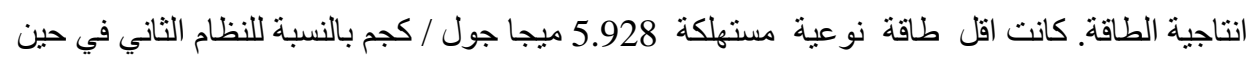

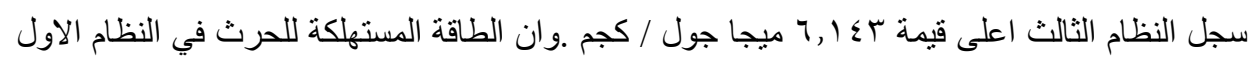

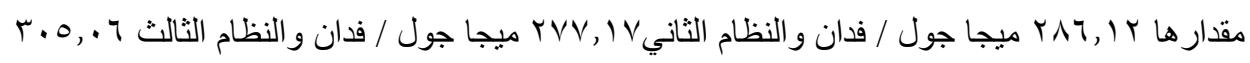
ميجا جول / فدان من الطاقة الكلية المستهلكة في كل نظام. وبالتالي يمكن ان نلخص ان النظام الثاني كان اعلى كفاءة في هذا البحث لان حاصل حبوب القمح الناتج من زراعة الفدان الواحد بالنظام الثاني

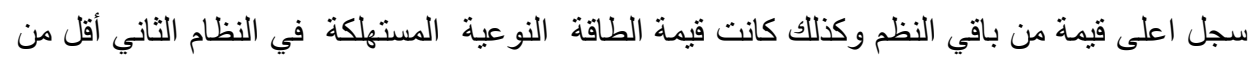
باقي النظم ويؤدي تقليل تكاليف الوقود المستهلكة الى تقليل تكاليف الانتاج. ويوصي البحث بتطبيق النظام الثاني في اجر اء العمليات الحقلية لانتاج محصول القمح. 